\title{
Aktuální pohled na francouzské vzdělávání. Zpráva o studijní návštěvě
}

Francie má za sebou období po velké školské reformě z roku 2005, která byla ustanovena zákonem „O profesní dráze a programu pro budoucnost škol“,1 a s tímto školním rokem byla zahájena realizace zatím poslední rozsáhlé reformy ustanovené zákonem z 8. 7. 2013 s názvem „Zákon o profesní dráze a o znovuzřizení školy“. ${ }^{2}$

Seznámení s vybranými problémy dnešního francouzského vzdělávání mi umožnil studijní pobyt na univerzitě Université Paris 8 . Uskutečnil se v rámci poskytnutého stipendia francouzskou vládou a byl zaměřen především na získání údajů pro vznikající publikaci Školní vzdělávání ve Francii a rovněž na získání informací o přechodu z mateřské do základní školy, což je tématem mé disertační práce. S ohledem na zaměření stáže byly klíčovými aktivitami rozhovory s odborníky na témata daná stanoveným obsahem publikace, návštěvy $v$ základní a mateřské škole a rozhovory s pedagogy různých stupňů a typů škol a studium materiálů dostupných na univerzitě.

\section{Aktuální témata $v$ oblasti vzdělávání ve Francii - školské reformy a úspěšnost pro všechny}

Reforma z roku 2005 byla do velké míry iniciována analýzou výsledků v rámci mezinárodního šetření PISA, které poukázaly na problematické oblasti francouzského školství. Francie tradičně zaujímá průměrné místo mezi testovanými zeměmi, ${ }^{3}$ nicméně podrobnější analýza dat ukázala na velké rozdíly mezi jednotlivými žáky. Pro analýzu neúspěšnosti některých žáků u testů PISA je možné se zaměřit nejen na jejich sociokulturní původ, ale i na to, na které úrovni ve vzdělávacím systému se nacházejí. Ve Francii mohou být testovaní 15letí na více místech v rámci vzdělávacího systému. Pokud žák nikdy neopakoval ročník, je ve druhém ročníku lycea, pokud byl přijat do školy dřive, tak už dokonce v ročníku prvním. ${ }^{4}$ Žák, který opakoval ročník jedenkrát, je ve třetím ročníku collège, a ten, který opakoval dvakrát, dokonce pouze v ročníku

Loi d'orientation et de programme pour l'avenir de l'école.

La loi d'orientation et de programmation pour la refondation de l'École.

Těsně pod průměrem $O E C D$.

Ve Francii se ročníky počítají obráceně, lyceum začíná ročníkem druhým. 
čtvrtém. ${ }^{5}$ Vyčlení-li se z analýz pouze žáci, kteři se nacházejí již na lyceu (což je cca 50 \% testovaných), je možné zjistit, že jejich výsledky jsou vynikající, a dokonce přesahují i výsledky dosahované tradičně nejlepšími zeměmi (Japonsko, Finsko). Oproti tomu ale výsledky žáků, kteří opakovali ročník, jsou více než podprůměrné (cca $25 \%$ testovaných) a u těch, kteří opakovali dvakrát (cca $15 \%$ testovaných), jsou dokonce, dalo by se ríci, katastrofální a bliží se výsledkům nejchudších zemí OECD (Mexiko, Turecko). Pohled na tyto výsledky může vést k tvrzení, že Francie má jeden z nejlepších vzdělávacích systémů světa, ale pouze pro polovinu svých žáků. Jaká informace $z$ této analýzy tedy pro Francii vyplývá? Není to pouze vliv sociálního původu na výsledky dětí, ale spiše to, v jakém ročníku se žáci nacházejí. Bohužel je to právě sociální pưvod, který má největší vliv na to, zda žáci opakují, nebo neopakují ročníky (Forestier, 2007).

Ve Francii vedla analýza výsledků $\mathrm{k}$ tomu, že bylo nutné změnit cíl rovného př́stupu ke vzdělání za rovnost dosahování vzdělávacích výsledků. Tento cíl rovnosti ve výsledcích vedl postupně $\mathrm{k}$ reformě z roku 2005 a $\mathrm{k}$ zavedení společného základu vědomostí a kompetencí, který má zajistit právě dosahování určité úrovně u všech sociálních skupin. Úroveň kompetencí je u jednotlivých žáků systematicky testována tak, aby se $s$ předstihem odhalily př́padné problémy s učením a mohla být včas poskytnuta adekvátní pomoc. Tento systém má zamezit právě onomu problematickému opakování ročníku, které je považováno za základ neúspěchu některých žáků $v$ testování PISA (Forestier, 2007).

V tomto školním roce se začala realizovat další, a zatím tedy poslední, školská reforma, která zasahuje více oblastí francouzského školství a je tématem řady odborných i neformálních diskuzí mezi odborníky i laickou veřejností. Významnou a ve Francii velmi diskutovanou změnou, kterou tento zákon přinesl, je reforma školního rytmu. $V$ roce 2010 vyústily stále aktuální debaty o zajištění úspěšnosti všech dětí k experimentálnímu kroku v celkem 124 zařízeních ve Francii, a to $\mathrm{k}$ úpravě školního rytmu, tak aby méně zatěžoval žáky. Do této doby byly všechny týdenní hodiny rozděleny do čtyř dnů (pondělí, úterý, čtvrtek, pátek) ${ }^{6}$ a vyučování probíhalo do pozdních odpoledních hodin. Řada odborníků poukazovala na velkou zátěž, je-li vyučování takto intenzivní. Proto se ministerstvo školství rozhodlo pro experimentální krok a v pilotních zařízeních zařadilo stěžejní předměty na dopoledne (tj. francouzštinu, matematiku apod.) a sportovní aktivity a výchovy na odpoledne a zároveň zkrátilo vyučování do 15.30 z původních 16.30 a zavedlo školu i ve středu dopoledne. Tento pilotní program byl realizován ve třech školních rocích a jeho analýza poté ukázala na prospěšnost takového rozdělení výuky; proto byl od začátku tohoto školního roku tento rytmus doporučen pro všechny francouzské primární školy a od školního roku 2014/15 bude zaveden povinně. Učitelé ale s touto reformou spokojeni zpravidla nejsou. Z rozhovoru s francouzskými učitelkami z různých typů škol vyplynulo, že

5 I na collège se počítají ročníky obráceně, posledním ročníkem collège je ročník třetí.

6 Zavedení čtyřdenního výukového týdne s volným jedním dnem (kterým je od roku 1972 středa) souvisí s oddělením státu a církve z roku 1905, na základě kterého byla vyloučena výuka náboženství ze vzdělávacích programů, a proto byl uvolněn jeden den v týdnu právě pro možnost soukromého docházení na náboženství 
nikdo z nich nechce mít pětidenní pracovní týden a že jim více vyhovuje rozdělení práce do čtyř dnů, jak to bylo dosud.

Reforma školních rytmů nás asi čeká všechny od přištího školního roku, ale nikdo z nás ji nechce (smích), to je jasné, jsme rádi, že můžeme být dva dny v práci a pak si jeden den odpočinout. Nevidím $v$ tom ani velký smysl, myslím, že by to mohlo zưstat tak, jak to je ted'. (Sabine Vincent, ředitelka MŠ Emile Zola)

Rovněž došlo k reformě v oblasti přípravy budoucích pedagogů a vznikla nová vysoká škola pro př́pravu budoucích učitelů - od školního roku 2013/14 jsou učitelé připravováni na specializovaných Vysokých školách pedagogických ${ }^{7}$ (ESPÉ). IUFM ${ }^{8}$ jako tradiční místo pro př́pravu učitelů se vznikem těchto škol zaniklo. Na ESPÉ jsou studenti připravováni k získání speciálního učitelského magisterského titulu. ${ }^{9}$ Vzdělávání obsahuje kromě všeobecného společného základu specializovaná témata dle volby studentů a praktickou část, která zahrnuje stáže ve školách, observace a hospitace $v$ hodinách a rovněž samostatnou prímou pedagogickou činnost. Zároveň jsou studenti systematicky připravováni k celostátním konkurzům. ${ }^{10} \mathrm{~V}$ případě, že u konkurzu poprvé neuspějí, dává jim tato škola možnost dalšího ročního vzdělávání za účelem zlepšení jejich profesní přípravy pro konkurz v dalším roce. ${ }^{11}$

ESPÉ očima francouzské učitelky:

Já jsem ještě prošla tradičním vzděláváním na IUFM a jsem ráda, protože na IUFM jsme dělali konkurz už na konci prvního ročníku a ve druhém ročníku jsme byli už státními zaměstnanci - stážisty, takže nám bylo studium vlastně placeno, navíc jsme měli hodně praxe. Dneska mají studenti na ESPÉ praxi jenom dvakrát za rok, nejsou zaměstnáni, a ani placeni a pak jdou hned pracovat do škol. Myslím si, že to spíše zhoršilo přípravu učitelů, chybí tam kontakt s praxí a je př́liš teoretická (Claire Benveniste, učitelka na základní škole v oblasti prioritního vzdělávání).

Z dalších změn je možné zmínit podporu inkluzivního vzdělávání pro všechny jakkoli handicapované žáky a zvýšení počtu míst osobních asistentů, zavedení výuky práce s informačními technologiemi již od primární školy a rovněž přípravu budoucích učitelů na práci s IT ve výuce. Zvýšená pozornost je také věnována předávání hodnot Republiky žákům - v každé francouzské škole má být vyvěšena deklarace

7 Écoles supérieures du professorat et de l'éducation (ESPÉ).

8 Les instituts universitaires de formation des metres (IUFM) byly založeny $v$ roce 1989 a lze je přeložit jako „univerzitní instituty pro vzdělávání učitelư“. V období mezi lety 2006-2009 byly IUFM integrovány do klasických univerzit a od roku 2010 bylo pro budoucí učitele zavedeno povinné magisterské vzdělání (tj. pětileté vysokoškolské studium, do tohoto roku bylo dostačující tříleté univerzitní vzdělání).

9 Métiers de l'enseignement, de l'éducation et de la formation (MEEF)

10 Zájemci o učitelskou profesi musí ve Francii kromě povinného studia úspěšně absolvovat i tzv. konkurz, což je v podstatě určitý typ zkoušky, po jejímž úspěšném zvládnutí se student stává státním zaměstnancem - učitelem. Uspěšnost závisí nejen na znalostech studentů, ale také na počtu volných míst, která stát pro učitele $v$ daném roce má. Náročnost konkurzů se $v$ posledních letech ve Francii snížila, a $v$ některých předmětech se dokonce stává, že je více volných míst než zájemců o absolvování konkurzu.

11 Dostupné z http://www.education.gouv.fr/espace-recrutement/. 
152 lidských práv a symbolů Republiky. V rámci rozvoje hodnot se zrrídila místa asistentů primární prevence a jejich činnost se zaměřila na prevenci šikany. Celkově došlo k posílení počtu pedagogických pracovníků (cca o 6000), klade se důraz na podporu vztahu rodičů a školy. A stejně tak jako $v$ předchozích reformách se zdůrazňuje boj proti školnímu neúspěchu všech dětí. ${ }^{12}$

\section{Navštívené školy a realizované rozhovory}

\section{École primaire publique Émile Bollaert}

Jedná se o školu v oblasti prioritního vzdělávání, která má jedny z nejnáročnějších žáků, jak vyplynulo z komunikace s učitelkou. V rozhovoru s učitelkou této školy Claire Benveniste jsme hovořili o prioritním vzdělávání, náročnosti pedagogické práce $v$ této oblasti, ale i o tom, proč si někteří francouzští učitelé dobrovolně volí právě takto náročné školy. Důvodem bývá cíl získat jednak vyšší plat, ale především snaha získat stabilní místo. Začínající učitelé ve Francii zpravidla nezískávají hned svoji třídu, ale spiše jsou využíváni jako suplující učitelé pro více škol, což je pro mnohé nevyhovující situace. ${ }^{13}$

Je možné říci, že po dokončení školy má člověk jenom dvě reálné možnosti - bud' být umístěn jako suplující učitel, nebo jít do hodně náročné školy. Pokud chcete být v určité lokalitě nebo třeba s kolegy ze studií, tak si musíte vybrat tu nejnáročnější školu, tam jsou místa vždycky. Já jsem letos ve čtvrtém roce praxe a rozhodla jsem se spolu se svými několika kolegy, že už nechceme dělat jenom suplování, tak jsme si společně zvolili tu nejnáročnější školu $v$ akademii. Je to sice složitá práce, sama bych do této školy nešla, ale je to lokalita, kterou jsem chtěla, a pracuji s lidmi, se kterými jsem chtěla (Claire Benveniste, učitelka na této škole).

Vzhledem $\mathrm{k}$ tak náročnému prostředí školy nebylo možné povolit návštěvu bez souhlasu inspektorky, který se ale vzhledem k bližícím se prázdninám nepodařilo $v$ termínu získat. Návštěva školy se proto bohužel nerealizovala.

\section{École maternelle Emile Zola, Sebrán}

Tato mateřská škola se nachází v oblasti prioritního vzdělávání, proto má upraven vzdělávací program tak, aby zahrnoval více hodin výuky a rozvoje francouzského jazyka. Zvýšení dotace hodin na francouzštinu je typickým znakem v prioritních školách ve Francii. Snaži se tak podpořit francouzštinu u dětí, které pocházejí z nepodnětného nebo cizojazyčného prostředí.

$\checkmark$ této škole jsem měla možnost pobýt celý den a sledovat učitelky i děti při výchovně-vzdělávací činnosti a hovořit s pedagogy i nepedagogickými pracovníky, kteří pưsobí

12 Dostupné z http://www.education.gouv.fr/cid73417/annee-scolaire-2013-2014-refondation -ecole-fait-rentree.html.

13 Ve Francii si učitelé nemohou vybrat samostatně místo svého působiště, ale jsou do škol centrálně umíst’ováni podle určitého počtu bodů, které získávají na základě seniority, ale i na základě působení v méně atraktivních školách a lokalitách. 
ve trrídách jako tzv. asistenti. V rozhovorech jsem se zaměřila především na způsoby práce s dětmi, hodnocení dětí14 a př́pravu na přechod do základní školy a rovněž jsme diskutovali o poslední školské reformě. V mateřské škole je stejný rozvrh dne a harmonogram školního roku jako ve škole základní, děti mají čas na „výuku“ a poté přestávky. Celý systém vzdělávání je více školní, než je tomu u nás, a řizená činnost probíhá v dopoledních i odpoledních hodinách. Vzdělávací nabídka je uzpůsobena věkovým specifikům tohoto období, nicméně podíl rízené činnosti je mnohonásobně vyšší než u nás. Činnost učitelky zahrnuje pouze výchovně-vzdělávací aktivity, ostatní „péči“ o děti (převlékání, toaleta apod.) vykonávají nepedagogičtí asistenti.

\section{Collège Robert Doisneau}

Tato collège se nachází rovněž v oblasti prioritního vzdělávání a dle informací do ní dochází řada dětí čínské národnosti vzhledem k lokalitě, kde se škola nachází. Stejně jako v mateřské škole, je i v této škole zvýšená dotace hodin francouzského jazyka, a to především z toho důvodu, že řada dětí nepochází z francouzských rodin. Děti, které přicházejí do školy bez znalosti francouzštiny, mohou první dva roky docházet do speciální třídy - accueil, kde se učí především francouzský jazyk a postupně k němu přidávají i ostatní předměty, po zvládnutí jazyka jsou přeřazeny do běžné třídy.

$\checkmark$ této škole jsem měla možnost hospitovat na hodinách francouzského jazyka a literatury, nahlédnout do vzdělávacího plánu a rovněž hovořit s několika rưznými učiteli. Tématem rozhovoru byla kromě specifik vzdělávání cizinců a práce $v$ prioritním vzdělávání také př́prava na zkoušku na konci collège, která je v podstatě první oficiální zkouškou dokládající dosažení základního vzdělání a průběh volby další vzdělávací dráhy. Rovněž jsme diskutovali o pozici učitele, jeho pracovní náplni a o rozdílech $v$ této oblasti mezi oběma zeměmi.

\section{Závěr}

Je zřejmé, že francouzský školský systém vykazuje řadu odlišností od českého systému. Nejvíce viditelné rozdíly panují v oblasti předškolního vzdělávání, které má ve Francii již ryze školský charakter a zahrnuje v podstatě klasické vyučování typické u nás až pro období povinného vzdělávání. Rovněž role učitelů je zaměřena výhradně na odbornou pedagogickou činnost, veškeré ostatní aktivity vykonávají jiní zaměstnanci a asistenti. Rozložení výukových hodin do čtyř dnů bylo ve Francii do začátku tohoto školního roku zcela specifické, nicméně se současnou reformou školních rytmů, která rozkládá učivo do celého pracovního týdne, se přibližuje tomu, na co jsme zvyklí v České republice. Propracovaným systémem prioritního vzdělávání se francouzské školy snaží vyrovnat relativně velké sociální a kulturní rozdíly

14 Ředitelé sevanských mateřských škol vytvořili ve spolupráci se školním inspektorem nový hodnotící nástroj - sešit, jehož smyslem je komplexní hodnocení dítěte a měl by sloužit i při přechodu na základní školu. 
154 mezi jednotlivými dětmi, a přispět tak ke školní úspěšnosti všech žáků. Efekt těchto opatření je nicméně diskutabilní.

\section{Literatura}

Année scolaire 2013-2014: La refondation de l'École fait sa entrée. Dostupné z http://www .education.gouv.fr/cid73417/annee-scolaire-2013-2014-refondation-ecole-fait-rentree .html.

Forestier, C. (2007). Égalité ou compétition? L'impact des comparaisons internationales. Pouvoirs, 3(122), 109-123. Dostupné z www.cairn.info/revue-pouvoirs-2007-3-page-109.htm.

Le recrutement à l'éducation nationale. Dostupné z http://www.education.gouv.fr/espace -recrutement/.

Zuzana Svobodová zuzana.svobodova@pedf.cuni.cz 